\title{
PARABIBLICAL AND BIBLICAL CHRONOGRAPHIC COMPILATIONS IN SIMEON'S BULGARIA
}

\author{
Anna-Maria Totomanova \\ Sofia University “St. Kliment Ohridski”, Sofia, Bulgaria
}

\begin{abstract}
The paper explores the role of a lost Byzantine chronographic compilation in shaping Bulgarian historiographic model in the early $10^{\text {th }} \mathrm{c}$. The compilation was translated into Bulgarian by order of Tsar Simeon the Great and survived in five Russian copies of $15-16^{\text {th }} \mathrm{cc}$. belonging to a closed textological recension with strong traces of a Glagolitic Old Bulgarian original.

The first part of the compilation contains a large and coherent excerpt of Africanus Chronography that gives a concise but exhaustive account of the Christian history of the world from the Creation up to the Resurrection of Christ. The second part includes a shorter excerpt, taken from a codex, which contained the second volume of the Chronicle of Synkellos and the chronicle of Theophanes the Confessor. Unlike Synkellos/Theophanes text, Africanus excerpt reveals traces of a serious editorial intervention. The Greek editor(s) left aside all Africanus notices about the preOlympic history of all other nations besides the Jews but kept intact his Christological and chronological concepts that treat the history of human kind as a predetermined execution of the Divine Providence in Six Millennia/days.

The recent studies on the structure and sources of an impressive chronographic compilation ordered by Tsar Simeon and known as the Chronograph of the Archive or Jewish Chronograph allow us to presume that this Chronograph represents an enlarged version of Africanus excerpt, in which the paraphrase of the first nine biblical books is replaced with a large Old Testament compilation.

Key words: parabiblical and biblical compilations, Julius Africanus, Simeon the Great, Chronograph of the Archive, historiography.

Citation. Totomanova A.-M. Parabiblical and Biblical Chronographic Compilations in Simeon's Bulgaria. Vestnik Volgogradskogo gosudarstvennogo universiteta. Seriya 4, Istoriya. Regionovedenie. Mezhdunarodnye otnosheniya [Science Journal of Volgograd State University. History. Area Studies. International Relations], 2017, vol. 22, no. 5, pp. 132-141. DOI: https://doi.org/10.15688/jvolsu4.2017.5.13
\end{abstract}

УДК 94(479.2)“07/08”

Дата поступления статьи: 04.08.2017

ББК 63.3(4Бол) 5

Дата принятия статьи: 31.10 .2017

\section{ПАРАБИБЛЕЙСКИЕ И БИБЛЕЙСКИЕ ХРОНОГРАФИЧЕСКИЕ КОМПИЛЯЦИИ В БОЛГАРИИ ВРЕМЕНИ ЦАРЯ СИМЕОНА}

\author{
Анна-Мария Тотоманова \\ Софийски университет «Свети Климент Охридски», г. София, Болгария
}

\begin{abstract}
Аннотация. Статья прослеживает влияние одной утерянной византийской хронографической компиля^ ции на историографическое мышление болгар в первой половине Х столетия. Компиляция была переведена 글 Болгарии по приказу царя Симеона и дошла до нас в пяти русских списках XV-XVI вв., восходящих к одной 亿 и той же редакции с заметными следами болгарского глаголического оригинала.

Первая часть компиляции содержит большое и связанное извлечение из хронографии Юлия Африкана, которое излагает вкратце мировую историю со дня Сотворения по Воскресение Христа. Вторая часть содержит один более короткий эксцерпт, заимствованный из общего издания хроник Георгия Синкелла и Феофана Исповедника. В отличие от части Синкелла-Феофана, часть Африкана претерпела серьезную редакцию - греческие составители устранили все сведения о доолимпийской истории древних народов за исключением евреев, сохранив при этом христологическую и хронологическую концепции автора, который (?) видел историю мира как исполнение Провидения Господня в течение шести тысячелетий/дней.
\end{abstract}


Новейшие исследования структуры и источников библейской хронографической компиляции, известной как Архивский или Иудейский Хронограф, наводят нас на мысль, что этот хронограф построен по модели компиляции, путем замены парабиблейского пересказа Африкана почти полным текстом первых девяти библейских книг.

Ключевые слова: парабиблейская и библейская компиляции, Юлий Африкан, царь Симеон, Архивский хронограф, историография.

Цитирование. Тотоманова А.-М. Парабиблейские и библейские хронографические компиляции в Болгарии времени царя Симеона // Вестник Волгоградского государственного университета. Серия 4, История. Регионоведение. Международные отношения. - 2017. - Т. 22, № 5. -C. 132-141. - DOI: https://doi.org/10.15688/ jvolsu4.2017.5.13

A chronographic compilation that covers the years from the Creation of the World up to the foundation of Constantinople in the $20^{\text {th }}$ year of Constantine the Great was the first parabiblical text translated from Greek into Old Bulgarian (OCS). The compilation is entitled HA(Y)HaO

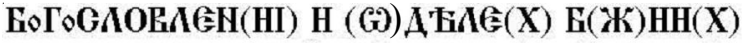

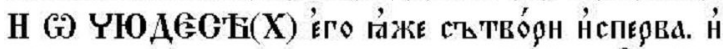

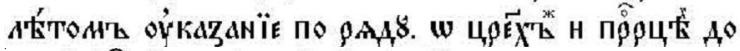

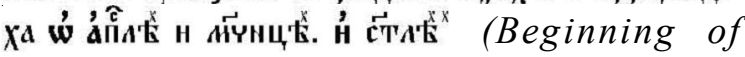
theologies and of the deeds of Our Lord, and of the wonders He worked first of all, and an account of the successive years of the kings and the prophets before Christ; of the apostles, the martyrs and the holy hierarchs) and has not been traced in the Greek manuscript tradition. The text starts with an introduction about the celestial hierarchy, which is inspired by the concept of Gregory the Theologian as presented in Orations XXVIII and XXXVIII. The Russian scholar Vasilij Istrin who studied the text more than a century ago and found some coincidences with the Chronicle of George Synkellos suggested that the Slavonic translation might contain an abridged or even draft version of his Chronicle [5, p. 381-414]. This hypothesis was silently accepted by the research community and only the 2008 edition of the full text known already as the Slavonic version of the Chronicle of George Synkellos and the respective textological and linguistic analyses refuted thoroughly Istrin's opinion [23]. The compilation survived in five Russian copies of $15^{\text {th }}-16^{\text {th }} \mathrm{cc}$. that belong to a closed textological redaction ${ }^{1}$ and the text itself reveals strong traces of a Glagolitic Old Bulgarian original [24]. The archaic morphological features and lexis, which is similar to the language of the Golden Age [20; 23, pp. 574-671; 21; 40; 37; 39] and to the idiolect of John the Exarch allow us to presume that this Bulgarian writer or someone of his literary circle, specialized in translating non canonical texts, made the translation of this rather complicated text. In all likelihood the compilation was translated into Bulgarian by order of Tsar Simeon the Great, who was eager to integrate Bulgaria into the Christian world and had received his education in the famous School of Magnaura [19].

The first part of the compilation contains a large and coherent excerpt from the Chronography of the first Christian chronographer Julius Africanus that was known only by a hundred relatively short fragments scattered in Greek, Latin and Arabic manuscripts. Africanus' excerpt gives a concise but rather exhaustive account of the Christian history of the world from the year of the Creation up to the Resurrection of the Lord, encompassing about two-thirds of the compilation's size (405a1-458b15 in Und. 1289). The historical narrative is complemented by another shorter excerpt (458b15-488b20 in Und. 1289), that in all likelihood was taken from the second volume of the common edition of the chronicles of George Synkellos and Theophanes the Confessor, which was widely spread in the Greek environment [32, p. XXVII]. This second part of the compilation contains the end of Synkellos' Chronicle and the beginning of the Chronicle of Theophanes. Unlike Synkellos'/ Theophanes' text that underwent some nonsignificant shortages [38], Africanus' part reveals traces of a serious editorial intervention. The Greek editor(s) left aside all Africanus' notices about the pre-Olympic history of all other nations except for the Jews but kept intact his Christological concept that treats the history of human kind as a predetermined execution of the Divine Providence. The first Christian chronographer genuinely believed that the Six Days of the Creation prefigured all Christian history and thus it could be displayed in six 
millennia/days. The historical narrative is organized according to two chronological lines. The main line reflects the Christological concept of Africanus and calculates the historical dates and periods by generations (i.e. the age of the Biblical Patriarchs by the time they had their first-born sons) and by rulers (i.e. periods of governance of different rulers of Israel). It has been found recently that such mode of calculation comes from the Jewish rabbinic tradition of Seder Olam that tries to explain chronological discrepancies in the Jewish Scriptures [25]. As a result the whole chronology is coherent and consistent with clearly defined periods [23, p. 574-586; 40; 37; 39]. The second, complementary, chronological line follows the Greek Olympic cycle whose first year according to Africanus' chronological scheme coincides with the first year of Achaz. It serves as an additional opportunity to organize the historical facts since unlike the pre-Olympic history that follows chronologically the first nine

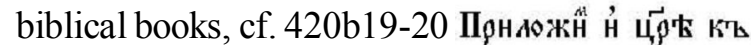

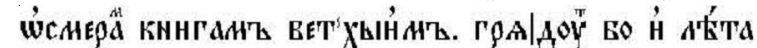
снै въ с с the Kings to the eight Old Testament books for chronologically they come after them), the Olympic history is more complicated and requires the use of more sources. The author of the text was aware of this challenge and referred to it when introducing the Olympic cycle: 433b26-434a1

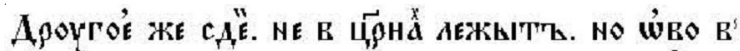

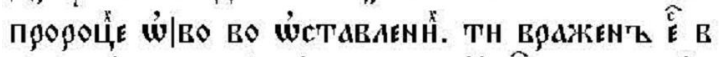

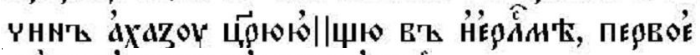

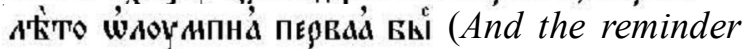
of it is not to be found here in the book of the Kings. Some things are in the Prophets some others in the Chronicles. And the canon includes also Achaz, the king of Jerusalem, in whose first year the first Olympiad took place). From this statement on the historical account, which to this point follows Samuel and Kings, includes interpolations from Chronicles, the books of Ezdras, Nehemiah, Tobith, Esther, Judith, and Maccabees, from Prophets (Daniel in the first place, but also Jonah, Amos, Isaiah, Jeremiah), that complement and enrich the main narrative. In cases when the biblical narrative itself lacks information about the history of Hellenistic states the author relies on some non-biblical sources the main one as well as in the preceding narrative being Josephus, whose Antiquities and to a less extent Jewish War provide the basic information about Ptolemaic dynasty, Seleucids and Rome of the time of the first emperors. Therefore while in the narrative about the pre-Olympic world history Josephus' notices are used as a complementary source here they constitute an integral part of the main narrative. The notices about ancient Greece and Roman pre-imperial period are simply woven into it under the respective Olympiads and most of them can be traced in Eusebius' Chronological tables $^{2}$. In fact the Olympic chronology helps to synchronize the biblical events with the history of Hellenistic states and ancient Rome, linking together at the same time the fragmentary notices about individuals and events related to ancient Greece and Rome ${ }^{3}$.

Africanus retells the Bible shaping his account according to above mentioned chronological concept that is thoroughly demonstrated by 23 chronological statements. The chronologies appear at crucial points of his narrative and a general chronology, repeating the most important dates and periods, marks the end of Africanus' excerpt in the compilation [40;37;39].

The second part is organized differently and the dates are not synchronized with Africanus' chronology apart from the date of the Flood that is mechanically corrected in the first part. It looks like that compiler(s) were looking for a suitable text to complement Africanus' account and extend it to the Foundation of the Constantinople.

It seems at first glance that the compilation did not influence the historical thinking of medieval Bulgarians, given the fact that it left no traces in the South-Slavonic milieu ${ }^{4}$.

There is however an impressive biblical chronographic compilation known as the Chronograph of the Archive, Judean [4] or Bulgarian Chronograph [3] and also as Bulgarian Historical Compilation of 921 [7; 31, p. 317-449]. Its earliest and most studied testimony of the late $15^{\text {th }} \mathrm{c}$. is kept in the Russian State Archive in Moscow, f. 181, 279/658 (A hereafter). So far only two other witnesses are known:

1. Warsaw copy of the late $15^{\text {th }}$ or early $16^{\text {th }} \mathrm{c}$. (codex 83 in the Polish National Library) that contains only the half of the compilation due to the loss of its ending (W).

2. Vilnius copy of the mid-sixteenth century (codex 146/107) that belongs to the manuscript collection of the Lithuanian academy of Sciences (V) ${ }^{5}$. 
The Chronograph of the Archive covers the world history from the Creation up to the dispersal of the Jews and the destruction of Jerusalem by Titus and Vespasianus. The whole text of the Chronograph according to the copy from the Archive (A) is available in electronic searchable format in the system Histdict, which contains a large corpus of medieval Bulgarian texts: http:// histdict.uni-sofia.bg/chronograph/clist.

The content of the Chronograph according to the oldest copy in short outline looks as follows:

1. ff. 10a-31a Narrative about the Creation, the Flood and the Tower of Babel based on Genesis I-XII with passages taken from John Chrysostom homilies on Genesis, John the Exarch's Hexaemeron and the Chronicles of John Malalas and George the Monk.

2. ff. 31a-43d Malalas books II-IV 6 .

3. ff. 43d-199a Genesis from chapter XIII (Joseph's departure from Egypt), and the rest of the Octateuch, namely from Exodus to Ruth.

4. ff. 199a-210a Malalas book V.

5. ff. 210b-295d I-IV Kings with interpolations from Isaiah, Jeremiah, Daniel and from George the Monk.

6. ff. 295a-311a Malalas books VI-VII.

7.311a-3443d Pseudo-Callisthenes Alexander romance and Malalas VIII.

8. ff. 343d-478r Josephus' Jewish War with interpolations from Malalas VIII-X up to the third chapter, excerpts from the Gospels on Christ's birth and account of the Magi from Aphroditianus.

It is followed by a chronographicon containing the list of Byzantine rulers (478r-481r), which is based on the Slavonic translation of Nicephorus I of Constantinople Chronographia brevis. The list starts with Constantine the Great and ends with Constantine VII and the coronation of Romanus Lecapenus as co-emperor in 920. The chronographicon has been published recently by $\mathrm{H}$. Trendafilov who pointed out also at the most significant differences between the text from the Archive collection and the one found in Coфиŭский хронограф $\left[31\right.$, p. 384-410] ${ }^{7}$. The last entry in the codex is the Chronicle of the Russian Tsars, which must be a later interpolation, given the fact that it is missing in Vilnius copy. The index of content of the codex (ff. 1-9) reveals that it was a part of a bigger manuscript, whose beginning and end went lost. The codex originally started with Andrew of Caesarea Commentary on Revelation and ended with a copy of the First Tsar Simeon's florilegium (whose earliest copy of 1073 is known as Svjatoslavov Izbornik) and the translation of the Greek gnomologium known as Melissa ${ }^{8}$.

During the preparation of the electronic edition of the text special attention was paid to the linguistic and textological features of the Biblical books included into the Chronograph. T. Slavova studied the text of Pentateuch [13], Judges [14] and Kingdoms [16;17; 11;18] and concluded that they contain archaic readings and linguistic characteristics allowing to presume that their translation was made on Bulgarian soil in the first decades after the arrival of the disciples of St. Cyril and St. Methodius in Bulgaria. She pointed out at the Glagolitic traces in rendering numbers and discovered three Glagolitic letters that remained intact in the text of Kingdoms. Based on the different translations of the same lexemes in Octateuch and Kingdoms she suggested that the compiler made up the codex using different sources. The latter was confirmed in a recently defended $\mathrm{PhD}$ thesis on the book of Kingdoms in the Slavonic chronographic tradition, which proved unequivocally that the translator of this biblical book was less experienced in rendering the Greek text into Bulgarian than the translator of the Octateuch and the text itself reflects an early translation, made in Bulgaria at the edge of $9^{\text {th }}$ and $10^{\text {th }} \mathrm{cc}$. before the norms of the so called Preslav redaction were set up [26]. Another dissertation of 2016 revealed an Old Bulgarian linguistic layer in the text of Josephus' Jewish War as a part of the Chronograph of the Archive, too [10]. These recent findings on textological and linguistic levels comply perfectly with the conclusions of a series of Bulgarian and foreign researchers who explain the occurrence of this biblical compilation with the political and cultural environment in the newly converted Bulgaria of the early $10^{\text {th }} \mathrm{c}$. Their opinion is far more justified given the fact that all tree witnesses of the text contain the famous note of Gregory the Presbyter that mentions the name of Prince Simeon in connection with the translation of the books of the Old Testament ${ }^{9}$. It is not occasional that the first glossa about Bulgarians/Myrmidons occurs in Malalas V (f. 200v), which follows Gregory's note and introduces Bulgarians in the world history, synchronizing their history to the 
history of King David and his successors. The Kingdoms and especially King David seem to be rather important to Simeon who strived to access the throne of the Byzantine emperors. The second mentioning of Bulgarians (this time identified with the Dacians) is placed in Josephus (f. 403v), whose work in the structure of the compilation prefigured the fall of Constantinople and fed Simeon's imperial ambitions [8].

The short chronographicon that closes the compilation also leads us to the time of Simeon not only because it ends with the coronation of Romanus Lecapenus that put an end to Simeon's personal aspirations for the throne in Constantinople, but also because such type of chronographic lists are found in other writings created during his reign - the so called Историкии (Histories) close the Didactic Gospels translated by Constantine of Preslav, dating it to the year 894; Chronographia brevis by Nicephorus I is placed at the end of Kormchaja book of 14 titles taken from the Greek Nomocanon and dates it around 912; Л $\mathbf{k}$ dating the first Simeon's florilegium between 917 and $919[29$, p. $432-439 ; 27$, p. $57-76 ; 30$, p. $291-$ $297^{10} ; 31$, p. 317-320, 411]. Similar dating function could be ascribed also to the epilogue to the edition of Four Epistles against the Arians by Anastasius of Alexandria, in which the copyist Theodore, son of Dux, informs the readers that the translation was commissioned by Simeon to Constantine of Preslav who finished it in 906 and he himself copied the book in 907 [31, p. 320-338].

The conceptual analysis of the content of the biblical compilation and its historiosophical rationalization leave no doubts that it constitutes an integral part of the literary production of Simeon's epoch and reflects his ideas of history and regal power. The codex was meant to inscribe the newly converted Bulgarians and their kingdom into the Christian history of the world thus justifying their dignity as successors of ancient nations and their right to challenge and eventually succeed to the biggest Christian empire of that time ${ }^{11}$. The Octateuch and the Kingdoms constitute the basic fabric of the narrative, in which are integrated stories from other biblical and non-biblical sources: mostly excerpts from Tobith, Jeremiah, Isaiah and Daniel as well as from the Chronicles of John Malalas and George the Monk, and from Josephus'Jewish War. In a way the Chronograph of the Archive represents an enlarged version of the parabiblical compilation, in which the paraphrase of the first nine biblical books from Africanus' Chronography was replaced with a large Old Testament compilation ${ }^{12}$, to which Jewish War was added. In all probability the unknown compiler of the Chronograph of the Archive borrowed the idea of the mosaic structure of the compilation from Africanus' excerpt, in which the biblical paraphrase is constantly complemented with information from other noncanonical and some pseudoepigraphic sources such as the Book of Jubilees and Enoch $2^{13}$. Yet the two compilations reflect different stages of the development of Christian historical knowledge and while in Africanus' excerpt Josephus is almost the sole non canonical source ${ }^{14}$ the compiler of the Chronograph relied also on John Malalas and George the Monk. The two compilations display also the different historiographic strategies and pathos of their creators: while the parabiblical compilation that includes Africanus' excerpt, was meant to serve the Byzantine missionary expansion amongst the new Christian nations in Central Europe and for this reason provided a short account of the Christian history from the Creation up to the foundation of the capital of the first Christian Empire as a second Rome, the Chronograph's compiler tried to justify the claims of Bulgarians and their ruler to a decent place in the Christian history. The latter explains the different chronographic framework of the biblical compilation, in which the historical account breaks up with the destruction of Jerusalem, and the different functions of the interpolations from the book of Daniel: while Africanus concentrated on the prophesy about Parousia of the Christ, especially on the oracle about the 70 weeks ${ }^{15}$, the compiler put the focus on the predictions about the destruction of Jerusalem and the dispersal of the Jews. At the same time the translation of the parabiblical compilation based on Africanus' excerpt and the biblical compilation in the Chronograph pursued similar goals: to introduce the newly converted Bulgarians to Old Testament History and give them information and knowledge about the history of Hellenistic states and GraecoRoman world. From this point of view the Chronograph of the Archive has to be viewed as a natural development of the chronographic thinking of Bulgarians according to the model set 
up by the first Christian chronographer Julius Africanus and developed by unknown Greek compilers and editors of the $9^{\text {th }} \mathrm{c}$. who complemented Africanus' account with Synkellos/ Theophanes excerpt.

\section{NOTES}

${ }^{1}$ Until the mid-1980s only four witnesses of the text were known: two Moscow, kept in RSL (Undol'skiy № 1289 (III +488 f.), $1^{\circ}$, f. 405-488b and Egorov № $9081^{\circ}$, (I+615 f.) f. 497-6151) and two Petersburg's copies, kept in the RSL (Sofiyskiy № 1474, II+ $397 \mathrm{ff} .4^{\circ}$; f. 34-135a and Soloveckiy№ 829/ $839,4^{\circ}, 656$ f.; f. 2-221a). The first two date to the fifteenth century and the second two - to the sixteenth century [28, p. 102; 6, p. 217). Traditionally the copy of Undol'skiy was believed to be the earliest and it lies in the basis of our 2008 edition. Recently however another copy of the chronicle from Egorov's collection was introduced into science (Egorov № 863), which has a dating (a marginal note of 1452) and is relatively earlier [1, p. 89-93]. Textologically Egorov № 863 does not differ from the other Moscow copies of which only the Undol'skiy manifests petite deviations mainly expressed in omissions, word shuffles and lexical changes [2, p. 106-118].

2 See the coincidences in table 1 in [23, p. 514-538].

3 About Greek and Roman notices in Africanus' part see [22].

${ }^{4}$ There are however excerpts from the compilation in some Russian mss [5, p. 383]. It is also worth mentioning that all 5 witnesses of the Slavonic text are published together with the Chronicle of George the Monk and only the two of them include other canonical, chronographic and antiheretical texts [23, p. 15-16].

${ }^{5} \mathrm{H}$. Trendafilov considers the so called $\mathrm{Co}$ фийский хронограф an abridged version of the Chronoraph of the Archive, calling it Petersburg copy, and gives information about another fragmentary version of the compilation kept in Moscow [31, p. 348349]. See there also a more detailed archeographic description of all copies.

${ }^{6}$ It is worth mentioning that some passages of Malalas IV (37a-40d) are repeated again as interpolations in the book of Judges [14, p. 171-173].

7 The copy of Vilnius, which in some places shows more correct readings than $\mathrm{A}$, does not include the list. Fr. Thomson considers this copy to be closer to the prototype of all three witnesses that have in common the apocryphal account of Sovii, who introduces the cremation instead of inhumation among the Balts. V lacks also some later interpolations, found in the copy of the Archive, such as the marginal comments taken from the Palaea Historica, written by the same hand that replaced the end of Genesis with an account of Jacob blessing his sons taken also from Palaea Historica and followed by the Testaments of the Twelve Patriarchs (ff. 65-88). In W the comments are included into the main text. In Thomson's opinion the compilation could be traced only to the late $13^{\text {th }} \mathrm{c}$. Grand Duchy of Lithuania where it was composed [36, p. 472-473].

8 The actual segmentation of the codex does not correspond to the segmentation of the index, the end of which is also missing [36, p. 473, n. 19].

9 About the function of the note that is placed between the Octateuch and Malalas V, which is preceding Kingdoms, see the publications of Peev and Slavova $[9 ; 12 ; 15]$ where a detailed survey on the opinions of the different scholars is made, and recently Thomson [36] who is not familiar with the publications of Peev and Slavova, and Trendafilov [31, p. 359-364].

${ }^{10}$ See there also the respective bibliography.

11 Such an approach to studying the codex is adopted and applied by Trendafilov [31] and Peev [10].

12 The idea that Africanus' excerpt might be the template of the Chronograph of the Archive was promoted for the first time by Hristo Trendafilov because of the Judaiocentric character of the both texts [29, p. 435-436].

13 About notices from pseudepigraphic texts in Africanus' excerpt see Badalanova Geller (see in [33, p. 193]).

${ }^{14}$ All Josephus' notices, identified by A. Totomanova [23, p. 514-537, tab. 1].

15 According his own testimony he wrote a special book on that, which has not survived, cf. $457 \mathrm{~b}$ of the excerpt 'We have proved this separately in more detail in a book we have written about the 70 hebdomads and this prophecy'. The statement is preserved also in the respective Africanus fragment in Synkellos [34, p. 392.1-393.27] and reproduced in Wallraf's edition of Africanus' fragments [35, F93, pp. 280.54-284.103].

\section{BIBLIOGRAPHY}

1. Анисимова, Т. Хроника Георгия Амартола в древнерусских списках XIV-XV вв. / Т. Анисимова. - М. : Индрик, 2009. - 464 с.

2. Бражникова, Н. В. Из наблюдений над списками славянского перевода Хроники Георгия Синкелла / Н. В. Бражникова // Лингвистическое источниковедение и история русского языка. - М. : Древлехранилище, 2000. - С. 106-118.

3. Горина, Л. Болгарский хронограф и его судьба на Руси / Л. Горина. - София : Тангра ТанНакРа, Общобългарска фондация, 2005. - 240 с. 


\section{ВИЗАНТИЙСКИЙ МИР}

4. Истрин, В. М. Александрия русских хронографов. Исследование и текст / В. М. Истрин. М. : Унив. тип., 1893. - viii, 361, [ii] c.

5. Истрин, В. М. Из области древне-русской литературы / В. М. Истрин // Журнал министерства народного просвещения. - 1903. - Ч. 339. - С. 381-414.

6. Творогов, О.В.Хроника Георгия Синкелла в Древней Руси / О. В. Творогов // Исследования по древней и новой литературе. - Л. : Наука, 1987. C. 215-219.

7. Димитров, П. Изборниците на цар Симеон / П. Димитров // Die slawischen Sprachen, Zeitschrift für Probleme slawischer Schriftsprachen und deren Benützer. - 1990. - Bd. 21. - S. 17-39.

8. Пеев, Д. Глоса за българите в славянския текст на Юдейската война от Йосиф Флавий / Д. Пеев // Старобългарска литература. - 2005. - Т. 3334. - C. 485-493.

9. Пеев, Д. Заглавката на Григорий, презвитер мних на всички църковници на българските църкви, и Именникът на българските ханове / Д. Пеев // Litera et Lingua. Електронно списание за хуманитаристика. 2007, Summer-Winter. - Электрон. текстовые дан. - Режим доступа: http://www.slav. unisofia.bg/naum/en/node/1615 (дата обращения: 31.07.2017). - Загл. с экрана.

10. Пеев, Д. Славянската версия на Юдейската война на Йосиф Флавий в контекста на Архивския хронограф : автореф. на дис. ... «доктор» / Пеев Димитьр ; Софийски ун-т «Свети Климент Охридски», Каф. кирилломефодиевистики. - София, 2016. - 53 с.

11. Славова, Т. Архаични лексеми и словообразувателни модели в старобългарския превод на библейската книга Царства / Т. Славова // Българска реч. - 2011. - № 3. - С. 42-51.

12. Славова, Т. Бележката с името на презвитер Григорий в Архивния хронограф / Т. Славова // За буквите. - 2012. - № 37. - С. 6.

13. Славова, Т. Библейското Осмокнижие в Архивния хронограф / Т. Славова // Palaeobulgarica/ Старобългаристика. - 2010. - Т. 34, № 3. - С. 26-48.

14. Славова, Т. Книга Съдии в Архивния хронограф / Т. Славова // Ricerche Slavistiche: Rivista dell'Universita degli Studi di Roma "La Sapienza". 2010. - Vol. 8 (54). - P. 169-191.

15. Славова, Т. Още веднъж за бележката с името на презвитер Григорий в Архивния хронограф / Т. Славова // Годишник на ЦСВП «Иван Дуйчев». - 2012. - Т. 98 (17). - С. 279-289.

16. Славова, Т. Пьрва и Втора книга Книга Царства в състава на Архивния хронограф (предварителни наблюдения) / Т. Славова // Palaeobulgarica/ Старобългаристика. - 2011. - Т. 35, № 1. - С. 3-16.

17. Славова, Т. Старинна лексика в библейския разказ за Соломоновия храм (вътръ, кладнво, коновъ) / Т. Славова // Сборник доклади от заключи- телната конференция «Компютьрни и интерактивни средства за исторически езиковедски изследвания» (София, 15.122011 г.). - София : Графис-Ал. Жеков, 2011.-C. 44-55.

18. Славова, Т. Трета Книга Царства в сьстава на Архивния хронограф (предварителни наблюдения) / Т. Славова // TRIANTAFYLLO. Юбилеен сборник в чест на 60-годишнината на проф. д.фил.н. Христо Трендафилов. - Шумен : ФАБЕР, 2013. - С. 151-163.

19. Тотоманова, А. Кой е преводачът на хронологическата компилация, известна като славянска версия на Хрониката на Георги Синкел? / А. Тотоманова // Преславска книжовна школа. Т. 14. - Шумен : Шуменски ун-т, 2014. - С. 348-357.

20. Тотоманова, А. Към историята на старобългарския аорист (по материали от славянската версия на хрониката на Георги Синкел) / А. Тотоманова // Българска реч. - 2007. - Т. 13, № 2. - С. 18-24.

21. Тотоманова, А. Названията на библейските книги в славянския ексцерпт от Хрониката на Юлий Африкан / А. Тотоманова // Palaeobulgarica/ Старобългаристика. - 2014. - Т. 38. - С. 46-53.

22. Тотоманова, А. Сведенията за грько-римския свят в славянския ексцерпт от Хрониката на Юлий Африкан. Проблеми на рецепцията / А. Тотоманова // Scripta slavica Mario Capaldo dicata / отв. ред. Кр. Дидди. - М. : Индрик, 2015. - С. 316-337.

23. Тотоманова, А. Славянската версия на хрониката на Георги Синкел. Издание и коментар / А. Тотоманова. - София : УИ «Св. Климент Охридски», 2008. - 684 с.

24. Тотоманова, А. Следи от глаголица и разсъждения за кирилицата в славянската версия на Хрониката на Георги Синкел / А. Тотоманова // Palaeobulgarica/ Старобългаристика. - 2007. - Т. 31, № 3. - С. 71-78.

25. Тотоманова, А. Юлий Африкан и еврейската равинска традиция / А. Тотоманова // Кирило-Методиевски четения 2015. Юбилеен сборник. - София : УИ «Св. Климент Охридски», 2015. - С. 33-43.

26. Тотоманова-Панева, М. Книга Царства в славянската хронографска традиция : автореф. на дис. за придобиване на образователната и научна степен «доктор» / Тотоманова-Панева Мария ; Cофийски ун-т «Свети Климент Охридски», Каф. кирилломефодиевистики. - София, 2016. - 26 с.

27. Трендафилов, Хр. Младостта на цар Симеон / Хр. Трендафилов. - София : ПАМ Пъблишинг Къмпани ООД, 2010. - 126 с.

28. Трендафилов, Хр. Наблюдения върху славянския превод на хрониката на Георги Синкел / Хр. Трендафилов / Palaeobulgarica/Старобългаристика. -1990. - Т. 14, № 4. - С. 100-110.

29. Трендафилов, Хр. Принос към историята на славяно-византийските хроники / Хр. Трендафилов // Slavia: časopis pro slovanskou filologii. - 2010. Ročnik 79. - P. 432-439. 
30. Трендафилов, Хр. Хронографиконът в Архивския хронограф / Хр. Трендафилов // Преславска книжовна школа. Т. 14. - Шумен : Шуменски ун-т, 2014. - С. 291-297.

31. Трендафилов, Хр. Цар и век. Времето на Симеона / Хр. Трендафилов. - Шумен : УИ «Епископ Константин Преславски», 2017. - 532 с.

32. Adler, W. The Chronography of George Synkellos. A Byzantine Chronicle of Universal History from the Creation / W. Adler, P. Tuffin. - Oxford : Oxford Univ. Pr., 2002. -638 p.

33. Badalanova, G. F. The Alphababet of Creation (Traces of Jubilees Cosmogony in Slavonic tradition) / G. F. Badalanova // Journal for the Study of Pseudepigrapha. - 2015. - Vol. 24, iss. 3. - P. 182-212.

34. Georgii Syncelli. Ecloga Chronographica/ed. A. Mosshammer. - Leipzig : BSB B.G. Teubner Verlagsges, 1984. - $507 \mathrm{~S}$.

35. Julius Africanus Chronographiae. The Extant fragments / ed. M. Wallraff. - Berlin ; New York : W. de Gruyter, 2007. - 351 p.

36. Thomson, Fr. Gregory the Presbyter of Bulgaria: the Man and the Myth / Fr. Thomson // Eвропейският югоизток през втората половина на $\mathrm{X}$ началото на ХІ век. История и култура. Международна научна конференция (София, 6-8 октомври 2014 г.). - София : БАН, 2015. - С. 468-511.

37. Totomanova, A. The Chronicle of Julius Africanus in Slavic Translation / A. Totomanova // Scripta \& e-Scripta. - 2012. - Vol. 10-11. - P. 227-236.

38. Totomanova, A. The Chronicle of Theophanes the Confessor in the Slavic Tradition / A. Totomanova // Travaux et memoires. - 2015. - Vol. 19 : Studies in Theophanes. - P. 207-235.

39. Totomanova, A. Giulio Africano e la tradizione storiografica slava / A. Totomanova // Vie per Bisanzio: VII Congresso nazionale dell' Associazione italiana di studi bizantini (Venezia, 25-28 Novembre 2009). Vol. 2. - Bari : Ed. di Pagina, 2013. - P. 749-769.

40. Totomanova, A. A Lost Byzantine Chronicle in Slavic Translation / A. Totomanova // Studia Ceranea. Journal of the Waldemar Ceran Research Centre for the History and Culture of the Mediterranean Area and South-East Europe. - 2011. - Vol. 1. - P. 191-204.

\section{REFERENCES}

1. Anisimova T. Khronika Georgiya Amartola $v$ drevnerusskikh spiskakh $X I V-X V v v$. [The Chronicle of George Hamartol in Old Russian Copies of 14-15 cc.]. Moscow, Indrik Publ., 2009. 464 p.

2. Brazhnikova N.V. Iz nablyudeniy nad spiskami slavyanskogo perevoda Khroniki Georgiya Sinkella [Some Remarks on the Testimonies of the Slavic Translation of Chronicle of George Synkellos].
Lingvisticheskoe istochnikovedenie $i$ istoriya russkogo yazyka [Linguistic Source Studies and History of Russian]. Moscow, Drevlekhranilishche Publ., 2000, pp. 106-118.

3. Gorina L. Bolgarskiy khronografi ego sudba na Rusi [The Bulgarian Chronograph and Its Fate in Rus]. Sofia, Tangra TanNakRa, Panbulgarian Fondation, 2005. $240 \mathrm{p}$.

4. Istrin V.M. Alexandria russkikh Khronografov. Issledovanie i tekst [Alexandria of Russian Chronografs. Study and Text]. Moscow, Univ. tip., 1893. viii, 361, [ii] p.

5. Istrin V.M. Iz oblasti drevne-russkoy literatury [From the Field of Old Russian Literature]. Zhurnal ministerstva narodnogo prosveshcheniya [The Journal of Ministry of People Education], 1903, vol. 339, pp. 381-414.

6. Tvorogov O.V. Khronika Georgia Sinkella v Drevney Rusi [The Chronicle of George Syncellos in Old Rus]. Issledovaniya po drevney i novoy literature [Studies on Old and Modern Literature]. Leningrad, Nauka Publ., 1987, pp. 215-219.

7. Dimitrov P. Izbornitsite na tsar Simeon [Tsar Simeon's Florilegia]. Die slawischen Sprachen, Zeitschrift für Probleme slawischer Schriftsprachen und deren Benützer, 1990, vol. 21, pp. 17-39.

8. Peev D. Glossa za bulgarite v slavyanskiya tekst na Yudeyskata voyna ot Yosif Flaviy [A Bulgarian Glossa in the Slavonic Text of Josephus' Jewish War]. Starobulgarska literatura [O1d Bulgarian Literature], 2005, vol. 33-34, pp. 485-493.

9. Peev D. Zavglavkata na Grigoriy, prezviter mnikh na vsichki tsurkovnitsi na bulgarskite tsurkvi, i Imennikut na bulgarskite khanove [The Title of Gregory the Presbyter Monk of all Bulgarian Clergymen and the Nominalia of the Bulgarian Khans]. Litera et Lingua. Electronno spisanie za khumanitaristika [Litera et Lingua. Electronic Journal in Humanities], 2007, Summer-Winter. URL: http://www.slav.unisofia.bg/naum/en/node/1615. (accessed July 31, 2017).

10. Peev D. Slavyanskata versiya na Yudeyskata voyna na Yosif Flaviy v konteksta na Archivskiya khronograf [The Slavic Version of Josephus' Jewish War in the Context of the Chronograph of the Archive]. Summary of PhD Thesis]. Sofia University "St. Kliment Ochridky". Department of Cyril and Methodius Studies, Sofia, 2016.53 p.

11. Slavova T. Arkhaichni leksemi i slovoobrazuvatelni modeli v starobulgarskiya prevod na bibleyskata kniga Tsarstva [Archaic Lexemes and Derivation Models in the Old Bulgarian Translation of the Book of Kingdoms]. Bulgarska rech [Bulgarian Speech], 2011, no. 3, pp. 42-51.

12. Slavova T. Belezhkata s imeto na prezviter Grigoriy v Archivniya Khronograf [The Note Containing the Name of Gregory the Presbyter in the 
Chronograph of the Archive]. Za bukvite [On the Letters], 2012, no. 37, p. 6.

13. Slavova T. Bibleyskoto Osmoknizhie v Archivniya Khronograf [The Biblical Octateuch in the Chronograph of the Archive]. Palaeobulgarical Starobulgaristika [Palaeobulgarica/Old Bulgarian Studies], 2010, vol. 34, no. 3, pp. 26-48.

14. Slavova T. Kniga Sudii v Arkhivniya khronograf [The Book of Judges in the Chronograph of the Archive]. Ricerche Slavistiche: Rivista dell'Università degli Studi di Roma "La Sapienza", 2010, vol. 8 (54), pp. 169-191.

15. Slavova T. Ozche vednuzh za belezhkata s imeto na prezviter Grigoriy v Arkhivniya Khronograf [Once Again about the Note Containing the Name of Gregory the Presbyter in the Chronograph of the Archive]. Godishnik na TsSVP "Ivan Duychev" [Annual of the Centre for Slavo-Byzantine Studies "Prof. Ivan Dujchev"], 2012, vol. 98 (17), pp. 279-289.

16. Slavova T. Purva i Vtora Kniga Tsarstva v sustava na Arkhivniya Khronograf (predvaritelni nablyudeniya) [The First and the Second Books of Kingdoms (1 and 2 Samuel) in the Structure of the Chronograph of the Archive (Preliminary Remarks)]. Palaeobulgarica/Starobulgaristika [Palaeobulgarica /Old Bulgarian Studies], 2011, vol. 35, no. 1, pp. 3-16.

17. Slavova T. Starinna leksika v bibleyskiya razkaz za Solomonoviya khram (вът тръ, кладнво, коновъ) [Archaic Lexis in the Biblical Narrative about Solomon's Temple (вътръ, кладнво, коновъ)]. Sbornik dokladi ot zaklyuchitelnata konferentsiya "Kompyuturni i interaktivni sredstva za istoricheski ezikovedski izsledvaniya" (Sofia, 15.12.2011) [Acta of the Final Conference "Computer and Interactive Tools for Diachronic Linguistic Studies" (Sofia, 15.12.2011)], Sofia, 2011, pp. 44-55.

18. Slavova T. Treta Kniga Tsarstva v sustava na Arkhivniya Khronograf (predvaritelni nablyudeniya) [The Third Book of Kingdoms (1 Kings) in the structure of the Chronograph of the Archive (preliminary remarks)]. TRIANTAFYLLO. Yubileen sbornik $v$ chest na 60-godishninata na prof., d. fil. n. Khristo Trendafilov [Triantafyllo. Festschrift on the Occasion of the $60^{\text {th }}$ Anniversary of Prof. Dr Habil Hristo Trendafilov], Shumen, FABER, 2013, pp. 151-163.

19. Totomanova A. Koy e prevodachut na khronologicheskata kompilatsiya, izvestna kato slavyanska versiya na Khronikata na Georgi Synkel? [Who Translated the Chronological Compilation Known as a Slavonic Version of the Chronicle of George Synkellos?]. Preslavka knizhovna shkola. Vol. 14 [Preslav Literary School]. Shumen, Shumenski un-t, 2014, pp. 348-357.

20. Totomanova A. Kum istoriyata na starobulgarskiya aorist (po materiali ot slavyanskata versiya na khronikata na Georgi Sinkel) [To the History of the Old Bulgarian (OCS) aorist (based on findings in the Slavonic Version of the Chronicle of George Synkellos)]. Bulgarska rech [Bulgarian Speech], 2007, vol. 13, no. 2, pp. 18-24.

21. Totomanova A. Nazvaniyata na bibleyskite knigi v slavyanskiya ekstserpt ot Khronikata na Yuliy Afrikan [Biblical Books Titles in the Slavonic Excerpt of the Chronicle of Julius Africanus]. Palaeobulgarica/ Starobulgaristika [Palaeobulgarica/Old Bulgarian Studies], 2014, vol. 38, pp. 46-53.

22. Totomanova A. Svedeniyata za gruko-rimskiya svyat v slavyanskiya ekstserpt ot Khronikata na Yuliy Afrikan. Problemi na retseptsiyata [The Graeco-Roman Notices in the Slavonic Excerpt of the Chronicle of Julius Africanus. Reception Problems]. Diddi Kr., ed. Scripta slavica Mario Capaldo dicata. Moscow, Indrik Publ., 2015, pp. 316-337.

23. Totomanova A. Slavyanskata versiya na khronikata na Georgi Sinkel. Izdanie i komentar [The Slavonic Version of the Chronicle of George Synkellos. Edition and Commentary]. Sofia, UI "Sv. Kliment Okhridski”, 2008. 684 p.

24. Totomanova A. Sledi ot glagolitsa i razsuzhdeniya za kirilitsata $v$ slavyanskata versiya na Khronikata na Georgi Sinkel [Glagolitic Traces and Comments about the Cyrillic in the Slavonic Version of the Chronicle of George Synkellos]. Palaeobulgarica/ Starobulgaristika [Palaeobulgarica/Old Bulgarian Studies], 2007, vol. 31, no. 3, pp. 71-78.

25. Totomanova A. Yuliy Afrikan i evreyskata ravinska traditsiya [Julius Africanus and the Jewish Rabbinic Tradition]. Kirillo-Metodievski cheteniya 2015. Yubileen sbornik [Cyrillo-Methodian Readings 2015. Festscrift]. Sofia, UI "St. Kliment Okhridski”, 2015, pp. 33-43.

26. Totomanova-Paneva M. Kniga Tsarstva $v$ slavyanskata khronografska traditsiya [The Book of Kingdoms in the Slavonic Chronographic Tradition. Summary of PhD diss.]. Sofia University"St. Kliment Okhridski“. Department of Cyril and Methodius Studies, Sofia, 2016. 26 p.

27. Trendafilov Khr. Mladostta na tsar Simeon [Tsar Simeon's Youth]. Sofia, PAM Publishing Company OOD, 2010. $126 \mathrm{p}$.

28. Trendafilov Khr. Nablyudeniya vurchu slavyanskiya prevod na khronikata na Georgi Sinkel [Some Remarks on the Slavonic Translation of the Chronicle of George Synkellos]. Palaeobulgarica/ Starobulgaristika [Palaeobulgarica/Old Bulgarian Studies], 1990, vol. 14, no. 4, pp. 100-110.

29. Trendafilov Khr. Prinos kum istoriyata na slavyano-vizantiyskite khroniki [Contribution to the History of Slavo-Byzantine Chronicles]. Slavia: časopis pro slovanskou filologii, 2010, Ročnik 79, pp. 432-439. 
30. Trendafilov Khr. Khronografikonut v Archivskiya khronograf [The Chronographic in the Chronograph of the Archive]. Preslavka knizhovna shkola. Vol. 14 [Preslav Literary School]. Shumen, Shumenski un-t, 2014, pp. 291-297.

31. Trendafilov Khr. Tsar i vek. Vremeto na Simeona [Tsar and Century. The Age of Simeon]. Shumen, UI "Episcop Constantin of Preslav", 2017. 532 p.

32. Adler W., Tuffin P. The Chronography of George Synkellos. A Byzantine Chronicle of Universal History from the Creation. Oxford, Oxford Univ. Pr., 2002. 638 p.

33. Badalanova G. F. The Alphababet of Creation (Traces of Jubilees Cosmogony in Slavonic tradition). Journal for the Study of Pseudepigrapha, 2015, vol. 24, iss. 3, pp. 182-212.

34. Mosshammer A., ed. Georgii Syncelli. Ecloga Chronographica. Leipzig, BSB B.G. Teubner Verlagsges., 1984. 507 p.

35. Wallraff M., ed. Julius Africanus Chronographiae. The Extant fragments. Berlin; New York, W. de Gruyter, 2007. 351 p.

36. Thomson Fr. Gregory the Presbyter of Bulgaria: the Man and the Myth. Evropeyskiyat yugoistok prez vtorata polovina na $X$ - nachaloto na XI vek. Istoriya i kultura. Mezhdunarodna naychna konferentsiya (Sofia, 6-8 October 2014) [The European South-East in the Second Half of the $10^{\text {th }}$ the beginning of the $11^{\text {th }} \mathrm{cc}$. International Scientific Conference (Sofia, 6-10 October 2014)], Sofia, 2015, pp. 468-511.

37. Totomanova A. The Chronicle of Julius Africanus in Slavic Translation. Scripta \& e-Scripta, 2012, vol. 10-11, pp. 227-236.

38. Totomanova A. The Chronicle of Theophanes the Confessor in the Slavic Tradition. Travaux et mémoires, 2015, vol. 19: Studies in Theophanes, pp. 207-235.

39. Totomanova A. Giulio Africano e la tradizione storiografica slava. Vie per Bisanzio: VII Congresso nazionale dell'Associazione italiana di studi bizantini (Venezia, 25-28 Novembre 2009). Vol. 2. Bari, Ed. di Pagina, 2013, pp. 749-769.

40. Totomanova A. A Lost Byzantine Chronicle in Slavic Translation. Studia Ceranea. Journal of the Waldemar Ceran Research Centre for the History and Culture of the Mediterranean Area and South-East Europe, 2011, vol. 1, pp. 191-204.

\section{Information about the Author}

Anna-Maria Totomanova, Doctor Habil, Professor, Head of the Department of Cyril and Methodius Studies, Sofia University "St. Kliment Ohridski”, Tsar Osvoboditel blvd., 15, 1540 Sofia, Bulgaria, atotomanova@abv.bg, http://orcid.org/0000-0001-9137-4945

\section{Информация об авторе}

Анна-Мария Тотоманова, доктор филологических наук, профессор, заведующая кафедрой кирилломефодиевистики, Софийски университет «Свети Климент Охридски», бул. Цар Освободител, 15, 1540 г. София, Болгария, atotomanova@abv.bg, http://orcid.org/0000-0001-9137-4945 